\title{
SOURCES OF RESILIENCE IN AGRICULTURAL COOPERATIVES: LESSONS LEARNT FROM 25 YEARS OF EXPERIENCE IN MURCIA (SPAIN)
}

Ignacio DE LOS RÍOS CARMENADO, Rural Development and Department of the Agroforestry, Technical University of Madrid (UPM), Escuela Superior de Ingenieros Agrónomos, Av. Complutense s/n, Spain. ignacio.delosrios@upm.es

Maria RIVERA, Sustainable Rural Development at the Agroforestry Department of the Technical University of Madrid (UPM), Escuela Superior de Ingenieros Agrónomos, Av. Complutense s/n, Spain. maria.rivera@upm.es

Carmen García FERRER, Project Planning for Rural Development and Sustainable Management at the Agroforestry Department of the Technical University of Madrid (UPM), Escuela Superior de Ingenieros Agrónomos, Av. Complutense s/n, Spain. carmen.garciaf@upm.es

Freddy Bolivar Lopez VILLAVICENCIO, Degree in theology of Universidad del Azuay. Ave 24 de Mayo 7-77, Cuenca 01.01.981, Ecuador. flopez@ups.edu.ec

Resilience is understood as the capacity of rural systems to transform and adapt, and this is key to achieving sustainable rural development. The aim of the research is to study resilience from a cooperative framework based on four concepts: persistence, adaptability, transformation capacity, and learning, and to collect successful strategies that encourage resilience. The research is part of a project called Rethink funded by the European Commission and state agencies of 14 European countries, included in the Seventh Framework Programme (FP7) and the ERA-NET RURAGRI. The methodology is structured based on a common analytical framework that holds the four concepts of resilience applied to each of the key stakeholders (cooperative, public sector, private sector and civil society). The case study analyzed is a cooperative that has more than 25 years' experience in agriculture during which it has demonstrated its capacity for renewal and recovery through its working model. The analysis covers the entire process of the cooperative, from previous experience of farmers, the creation of the company in 2007 to its current projects, focusing not only on market strategies, but also on its strategic vision and research investment, and on values such as trust and respect, on which the cooperative is based.

Keywords: adaptability; agricultural Cooperatives; persistence; resilience; social learning; transformability.

\section{INTRODUCTION}

The boom of the term resilience in recent years is due to the importance of being able to cope with changes. Usually this concept refers to the ability to quickly recover from adversity (Alexander, 2013). The origins of the concept are mainly based on the theoretical work of CS Holling (1973) and later on the research performed by the "Resilience Allianc" (Darnhofer et al., 2014) on socio-ecological systems (SES) (Berkes and Folke; 1998; Gallopin, 2006). In these SES resilience is defined as the ability of a system to absorb shocks and reorganize maintaining the same function, structure, identity and feedback (Walker et al., 2004: 4). Within this definition, three aspects of resilience can be distinguished: persistence, adaptability and transformation capacity (Walker et al., 2004; Folke et al., 2010). Persistence is understood as the ability to absorb impacts while maintaining the same function; adaptability is the ability to face challenges, or the capacity for renewal, reorganizing and learning. On the other hand, transformation capacity refers to radical change, that is, the ability to create a new system when the current is unsustainable. These three aspects are required for a system to be able to stay "dynamically stable". The key is not that these three aspects are applied equally but that one or the other is applied depending on the situation. Other researches have included learning into the concept of resilience (Lloyd et al., 2013; Davoudi et al., 2013), both individual and social learning, due to their relevance when having to restructure a system in response to shocks. Thus, the conceptual framework of socio-ecological systems resilience consists of four dimensions: persistence, adaptability, processing and learning capacity.

Moreover, to address the dynamics of resilience, four factors that have a strong social component are identified: 1) learning to live with change and uncertainty, seeing these situations as opportunities to learn from crisis; 2) promoting diversity and renewal to allow innovation, creativity and adaptation following disturbances; 3) combining different types of knowledge for learning; 4) creating opportunities for self-organization (Folke et al., 2003). Understanding resilience like this means that disturbances are not seen as something negative, but as opportunities that can generate and transform changes for the better, triggering mobilizations, and creating new knowledge and new ways of learning.

Copyright (C) 2015 The Authors. Published by Aleksandras Stulginskis University. This is an open-access article distributed under the terms of the Creative Commons Attribution License (CC-BY 4.0), which permits unrestricted use, distribution, and reproduction in any medium, provided the original author and source are credited. 
In the context of agricultural cooperatives, a broad and multidimensional approach is required that includes not only the social sciences, but also aspects related to the organization, management of resources and other contextual characteristics (Widgren, 2012). Agricultural associations (cooperatives and agricultural processing companies) are a main instrument for the economic development of rural areas that have to face the challenges of the XXI century.

Agricultural Cooperatives require "dynamic capabilities" (Teece, 2007), understood as the evolutionary fitness of an organization to identify opportunities and threats, seize opportunities and reshape its structures to remain competitive. The opening of new markets and all those aspects that escort globalization pose changes and challenges. The resilience of these cooperatives depends not so much on the resources available but on the way they are combined for the optimization of resources. What matters is knowing how to deal with the changes that occur and the best way of combining these "dynamic capabilities". Capacity building and skills development are therefore key elements closely related to resilient organizations and agrarian societies (Augier and Teece, 2009). At territorial level multiple elements that are a source of resilience to adapt to the challenges and hardships that arise from emerging opportunities and possibilities are also recognized (Shucksmith and Roningen, 2011). Associations and agricultural cooperatives have maintained economic activity linked to the territory and are an important backbone of rural areas.

The four dimensions involved the concept of resilience (persistence, adaptability, transformation capacity, and learning) are the pillars on which the analysis of the case study is based. Ultimately, the goal of this research is to analyze the strategies followed by a cooperative, as it has shown capacity for renewal and recovery through its working model. The analysis covers the entire process of the cooperative, from previous experience of farmers, the creation of the company in 2007 to its current projects, focusing not only on market strategies, but also on its strategic vision and research investment, and on values such as trust and respect, on which the cooperative is based.

\section{CASE STUDY}

The case study focuses on a cooperative called Camposeven located in the southeast of Spain, in the region of Murcia called "Campo de Cartagena". This is a legal form of civil society association with economic and social purpose in relation to production, processing and marketing of organic and conventional fruit and vegetables. Farm lands of Camposeven's partners are located in the municipalities of San Javier, San Pedro del Pinatar, Sucina and Pilar de la Horadada. This agricultural system has a total population of 358927 inhabitants and 1,163 km², representing $12 \%$ of the regional area and concentrates $17 \%$ of the farmland in the region, out of which $44 \%$ are irrigated crops. It has high technology and competitive agricultural systems (INFO, 2013). Camposeven was founded in 2007 by seven farmers that came from a very large fruit and vegetable cooperative (480 partners, 600 employees, 60 million euros in sales and 83,000 tons of production). These 7 farmers were in the larger cooperative for 25 years, which gave them great experience in the associative and horticulture sectors. Facing a divergence in the organization's strategy, these 7 farmers abandoned the previous cooperative to start together a new partnership project they called Camposeven. This change led by former managing director (current manager of Camposeven) was directed towards a new strategy for production and marketing of organic and biodynamic quality products based on confidence and transparency as key values for teamwork. The launch of Camposeven happened at the same time as the economic crisis, demonstrating the entrepreneurial character of the farmers. The seven partner families started the project with 200 hectares of land and 13 varieties of products. In 2008 , the first year of commercialization, the sales reached 7,056,871 euros (Camposeven, 2014). Its main product was and still is pepper, very common in Campo de Cartagena due to favourable weather conditions in the area. In 2011 the number of farming families rose to nine, and the number of hectares to 350, increasing production to 17,000 tons (Camposeven, 2014). Increasingly new technologies and new strategic partnerships were adopted increasing the $R \& D$ which has always been a hallmark of the organization. In 2014 the company had 125 workers, 490 hectares of production, 19,280 tons of 19 varieties of products and $€ 19,078,545$ of sales, out of which $90 \%$ are organic products, exported to other EU countries (Germany, Switzerland, England, France and Italy). At the end of 2014 farmers and cooperative partners received the Demeter certification under the international rules of biodynamic production, providing further differentiation at regional, national and international level. All these pillars are key elements to adapt to a changing, complex and difficult context. Participatory governance has allowed farmers to make decisions and direct their future. At the same time, these farmers have the control and management of their own farms, products, labour and marketing. Camposeven has its own technical, administrative and commercial team and also keeps external alliances with universities and other R\&D centres that advise them and cooperate in different projects.

\section{METHODOLOGY}

The analysis is part of a research project called Rethink which is funded by the European Commission and state agencies of 14 European countries, included in the Seventh Framework Programme (FP7) and the ERA-NET RURAGRI. This interdisciplinary project aims to "rethink the links between farm modernisation, rural development and resilience in a world of increasing demands and finite resources" (Rethink, nd). The work was conducted under a common framework where resilience within the socio-ecological context is defined according to Walker et al. (2004: 4) "the ability of a system to absorb disturbance and reorganize while undergoing change so even essentially retain the same function, structure, identity and feedbacks" and it is complemented by three aspects that are part of the concept itself: persistence, adaptability and transformation capacity (Walker et al., 2004; Folke et al., 2010) These three aspects interact under a central aspect of resilience, both individual and social learning (Davoudi et al., 2013). 
The first step was collecting information taking into account all parties directly related to the cooperative. The total number of people involved were 38 , distributed as shown in the following table:

Table 1 Pool of individuals interviewed

\begin{tabular}{|c|c|c|c|c|c|}
\hline \multicolumn{3}{|c|}{ Camposeven } & \multicolumn{3}{c|}{ Domain } \\
\hline Farming partners & Other farmers & Workers & Public & Private & Civil Society \\
\hline 10 & 7 & 5 & 5 & 8 & 3 \\
\hline
\end{tabular}

Source: Own elaboration

The collection of data was performed using two complementary participatory processes:

a) Direct interviews, for which five questionnaires were designed, one for each group of actors, with open and closed questions structured based on the common analytical framework of Rethink project (Darnhofer et al., 2014) and the principles of the WWP model ( Cazorla et al., 2012). All of them were conducted in person, between April 23 and July 7, 2014, for which the research team moved to the facilities and farms of the interviewees. The duration of these ranged between 60 and 90 minutes each.

b) Seminar-workshop on skills for February 28, 1, 7 and 8 March 2014, in the form of four Project-Based Learning workshops carried out by members of GESPLAN Group (De los Ríos et al., 2010, 2013, 2014; Diaz-Puente et al., 2009; Barrera et al., 2010; Cazorla et al., 2013). They were conducted in order to understand and analyze in depth the processes of management and operation of the cooperative.

\section{RESULTS}

The results are presented in an orderly manner from the four elements described as conceptual framework.

\section{a) Persistence of farming activity}

Camposeven is located in a region that mainly lives of services (MAGRAMA, 2014), where the climate and the quality of its beaches make it very attractive for tourism. The fruit and vegetables sector in the region of Murcia is top both nationally and internationally. It is the second province in Spain exporting horticultural products (valued at 2.251 million euros in 2013). The export destination is mainly the European market (98\% of fruit and vegetables destined for EU countries). The region of Murcia is currently the autonomous region with the largest proportion of acreage dedicated to organic farming (INFO, 2014). In this context, although the farming partners have the feeling that the sector is currently stabilized, most of them predict "a positive future for farming" because of the competitive advantage enjoyed by the region's strengths, both locally on their own farms and at regional levels (climate, agricultural tradition and experience, and the soil's fertility). In table 2, farmers identify the main strengths of their farms (1 very low and 4 very high): participation and teamwork, ongoing training of farmers specializing on organic farming; and awareness to protect the natural environmental. The mission of Camposeven defined as "Promoting the health of people by developing organic product lines through sustainable techniques", summarizes these strengths. Their high specialization in organic and biodynamic products is also considered strength, as this allows them to compete in the international markets. Linked to organic production, the protection of the environment is a principle accepted by all farming partners in order to maintain agricultural activity in the future; they all work and incorporate sustainable techniques in their farms to preserve the natural environment around them which is their main resource. However farmers do feel they must improve their roles as agricultural professionals in order to be more persistent to change.

Table 2. Persistence in agriculture: main strengths of Camposeven

Item

\begin{tabular}{lr} 
Item & Valu \\
Care for the people and continuous training & 3,7 \\
\hline Crop Specialization & 3,6 \\
\hline High level of environmental protection & 3,6 \\
\hline Adaptation capability & 3,5 \\
\hline Collaboration and teamwork between farmers & 3,4 \\
Trust and ethics in business & 3,4 \\
\hline Product Diversity & 3,3 \\
\hline Marketing Strategies Diversity & 3,2 \\
\hline Ability to withstand adversity & 3,2 \\
\hline R\&D & 3,0 \\
\hline Diversity of production strategies & 2,8 \\
\hline Little public aid dependency & 2,6 \\
\hline Diversity of economic activity & 1,6
\end{tabular}

Source: Own elaboration

Another decisive factor identified by Camposeven regarding persistence is the importance of interpersonal relationships in order for partners to be united when having to address decision making. This relationship between partners depends on personal values such as trust and transparency in management, which "encourages everyone to work towards the same goal which is oriented towards the common good of society". The opinion of all partners is that there 
is a need for collaboration and interaction between farmers and other actors. The decision-making in Camposeven does not respond to hierarchies or bureaucracies; decisions are usually made by consensus at weekly meetings of the Governing Board. This participatory governance which fosters collaboration exists because of the small number of members composing the cooperative, as well as the trust that exists among them. Because of their experience, partners believe that "in small cooperatives fewer problems arise between the partners because the number of people involved is lower." However, they consider that an advantage of large cooperatives is that they may be more persistent due to their greater influence on the market, greater access to larger customers, and lower production costs. Autonomy is also considered a necessary element of persistence. Adverse situations and unfavourable circumstances can be exceeded if there is autonomy in relation to financial, human and economic resources, which can help to take action faster and start new projects. The over-reliance on external factors and public aid may aggravate and complicate the situation. In Camposeven, partners considered they have a high degree of autonomy, because "they grow and market their products according to their choices, ideals, strategies and beliefs"; often they turn to their own agricultural technician when they need advice; they also do research in their own holdings. Also, the daily contact between partners is a source knowledge that gives them autonomy. Only when necessary, they turn to other, more expert and external expertise. It is very important that they depend very little (or nothing) on subsidies (mainly Operating Funds).

\section{a) Adaptability}

Regarding the sources of adaptability, Camposeven has developed a strategy to renew and reorganize its production in terms of their diversity of production systems, processing and marketing. Maintaining ecological specialization through organic fruit and vegetables, they have generated alternatives that show a diversity at different levels: Diversification strategies at production level, with more than twenty different products and different production systems (outdoors or greenhouse); certification processes (organic and biodynamic), quality processes (GlobalGap, Bio Suisse, Demeter), in stock (BRC, IFS, Bio Suisse, Demeter) and certification systems of their staff (IPMA project management); Diversification strategies in terms of commercialization, with short, medium and long chains and diversity of customers (national and international). Camposeven's adaptability has also focused on trying to overcome the problems that farms in the region face, adapting and reorganizing production processes. The most important challenge (see table 3 ) is the lack of water resources in the area, followed by the high cost of electricity for farms and pests in organic crops (due to the difficulty to fight them without using chemicals). Other difficulties that farmers mentioned are the consequences of climate change in the area (progressive increases in temperatures, less frequent rains but torrential when they do come which damage crops), increased market competition and the management of the unexpected. Likewise, they consider a challenge to manage properly the fluctuating workload throughout the year.

Table3. Major challenges in the adaptability process of Camposeven

\begin{tabular}{lcc}
\hline Item & Value \\
\hline Increase the cost of water & 3,7 \\
\hline Loss Key Resources & 3,6 \\
\hline Increased energy costs & 3,6 \\
\hline Pests & 3,6 \\
\hline Market pressures (increased competition) & 3,6 \\
\hline Variation prices & 3,4 \\
\hline Food crises (export barriers) & 3,3 \\
\hline New consumer expectations & 2,5 \\
\hline Unforeseen changes agricultural policies & 2,5 \\
\hline Insecurity agricultural policy changes & 2,3 \\
\hline Demographic issues (rural exodus) & 2,2 \\
\hline Climate change (lack of rain) & 2,2 \\
\hline Large debts (investments machinery) & 1,8 \\
\hline Pressure urban sprawl & 1,5 \\
\hline Source: Own elaboration & \\
\hline
\end{tabular}

All these challenges require Camposeven, and other cooperatives, a continuous renewal and innovation. The technical expertise gained over the years was essential for the creation of the new cooperative, as the experiences knowledge in horticulture was essential for adaptation and transformation into a new form of organic and biodynamic production. They have also considered other key factors for this adaptation process: the high level of trust between partners, and the clear commitment to research, innovation and new technologies. The adaptability of Camposeven has been especially shown during the recent economic crisis in Spain, as they have not only managed to adapt and reorganize, they have been able to continue growing annually, increasing sales, product portfolio and the number of employees.

\section{b) Transformation capacity}

Camposeven resilience, in terms of transformation capacity, has been based on a "radical change" to search for a new form of agriculture through innovation and the union of farmers. In this regards, Camposeven is based on an innovative business strategy that has been recognized through several awards, highlighting the "Thanit Award 2007 for 
Development and Technological Innovation in Agriculture". The partners interviewed believe that "our holdings are similar to those of the area, in terms of the type of product and conditions, but they are also very different because of what we do and how we act." Agents and institutions of the territory consider Camposeven a pioneering organization in the way they integrate R\&D into the ecological and biodynamic farming; they have managed to create strategic alliances, modern farming techniques and advanced technological facilities (for handling, processing and packaging).

In this process of transformation in Camposeven, radical changes happened (creating a processing center for handling cold food with separate lines for collection and processing). Farming partners said that "the holdings are following a process of transformation and modernization continuously". This process of modernization on holdings is mainly due to improvements in infrastructure and facilities, but above all "changes in the mentality and attitude of farmers" are observed. The radical change of creating Camposeven meant a great process of adaptation to this new associative system. The big challenge was to position their products in the competitive international market at the same time as meeting the needs of partners. The second challenge was minding the need for R\&D to improve farming techniques and processes; in 2013 they created their own field test for research topics of interest to farmers, together with the UPM and the research group "Plant Response Biotech". Farming partners believe that the quality of human relationships and the ability to team work has been the most important element to overcome adverse situations and crises, staying in the market and increasing sales.

Table 4 Camposeven's Milestones

\begin{tabular}{|c|c|c|c|c|c|c|c|c|}
\hline & $\mathbf{2 0 0 7 / 2 0 0 8}$ & $\mathbf{2 0 0 8 / 2 0 0 9}$ & $\mathbf{2 0 0 9 / 2 0 1 0}$ & $\mathbf{2 0 1 0 / 2 0 1 1}$ & $\mathbf{2 0 1 1 / 2 0 1 2}$ & $\mathbf{2 0 1 2 / 2 0 1 3}$ & $\mathbf{2 0 1 3 / 2 0 1 4}$ & $\mathbf{2 0 1 4 / 2 0 1 5}$ \\
\hline Sales (€) & 6.784 .024 & 4.341 .438 & 12.452 .348 & 8.185 .123 & 9.489 .920 & 14.747 .666 & 19.078 .545 & 22.781 .248 \\
\hline Milestones & $\begin{array}{c}\text { Creación } \\
\text { SAT }\end{array}$ & $\begin{array}{c}\text { Agrifood } \\
\text { Plataform }\end{array}$ & $\begin{array}{c}\text { IPMA } \\
\text { certification }\end{array}$ & $\begin{array}{c}\text { Food for } \\
\text { Life }\end{array}$ & Freshvana & $\begin{array}{c}\text { Plant } \\
\text { Response } \\
\text { Biotech }\end{array}$ & $\begin{array}{c}\text { Demeter } \\
\text { Diodynamic } \\
\text { products }\end{array}$ \\
\hline
\end{tabular}

Source: Own elaboration

\section{c) Learning}

People working in Camposeven have been willing to learn from the experiences of the past and situations experienced both individually and collectively with other people and farmers. They consider that this has been possible thanks to "the openness for cooperation and joint work" of everyone involved, and that the sustainability and success of Camposeven would not have been possible without their "ability to interact daily with other actors and stakeholders". Farming partners interact primarily through weekly meetings to share information and ideas. According to the partners, this fluid communication positively influences the increased level of trust and improves and facilitates collaborative decision-making processes. Learning also comes from the various sources of information (expert and experienced) that enables them to exchange ideas and update their information on different topics. In Camposeven's context, municipalities are small and with few inhabitants therefore most farmers know each other and their farms are closely located. Farmers often have similar schedules and work habits so at midmorning time they often take a break for lunch at the local bars and socialize among themselves and with workers in other sectors. Thus, informal networks where farmers exchange information and experiences are created. In addition, farmers also participate in events of recreational nature that take place in these villages such as fairs, festivals, etc. where these people involuntarily share their experiences and the circumstances they have faced creating mutual learning between them. However, farming partners understand that there is no sense of community among farmers in the area, only between those that cooperate through Camposeven. Other instruments that have gradually promoted individual and organizational learning are: in 2009 the inclusion of Camposeven into the Agrifood Platform with the UPM and the industry; in 2011 the integration into the European Platform Food for Life with different companies and horticulture research centres; in 2012 the relations with IPMA to adopt the culture of competence certification in Project Management; in 2013 the creation of the Chair Ingenio Foundation in collaboration with GESPLAN group and real estate companies.

\section{CONCLUSIONS}

In socio ecological systems, the term resilience refers to the ability to "recover" after undergoing a disturbance. In 2003, Bruneau et al. recognized the implication of strength, ingenuity and speed in responding to the difficulties faced, as key factors in the resilience of a system. Rose and Liao (2005) appreciate the adaptive measures as an element that prevents suffering significant losses. Also, Andersson (2006) emphasizes the importance of taking preventive measures to address the risks and response to threats. Moreover, in 2008, Perry Wears established as an antonym of the term resilience the term fragility due to the inability of a fragile system to adapt to the new situation. In particular, this research is based on the conceptual framework that defines resilience as formed by the aspects established by Walker et al (2004) and Folke et al. (2010): persistence, adaptability and transformation, and the proposed Davoudi et al. (2013): learning. The working model of Camposeven as cooperative and co-management in its decision-making process have also contributed to resilience. Olsson et al. (2004, p. 87) established that the adaptive co-management process provides the potential to make more robust socio-ecological systems change.

The main results of the research, divided according to the four concepts have been, in relation to persistence, the strengths submitted by both the context (climate, soil fertility, agricultural tradition and experience) and by the cooperative (care for the people and training, specialization in organic and biodynamic products, care for the environment), 
interpersonal relationships of confidence, and the empowerment of resources. On the other hand, in adaptability, diversification strategies, work based on principles and values such as trust, transparency, and participation, and all its experiences during these years are the key strategies. The transformation capacity of Camposeven is evident from the beginning when they leave the old cooperative and form their own; also their clear commitment to innovation; the types of products; marketing strategies; and the processing methods used. Investment in R \& D has also been significant as they have come to create their own field test in collaboration with Plant Response Biotech group. Finally, strategies that promote both individual and social learning create a favorable environment in the company, as well as the frequent meetings to encourage interaction and integration of the people involved and informal networks where farmers socialize among them. All these strategies have helped and have been instrumental for this cooperative to overcome the different situations and circumstances they have faced over the years.

\section{REFERENCES}

1. Alexander, D. E. 2013. Resilience and disaster risk reduction: An etymological journey. Natural Hazards and Earth System Sciences, Vol. 13, pp. 2707-2716. http://dx.doi.org/10.5194/nhess-13-2707-2013

2. Andersson, E. 2006. Urban Landscapes and Sustainable Cities. Ecology and Society, Vol. 11, No. 1, Iss. 1, Art. 34. http://www.ecologyandsociety.org/vol11/iss1/art34/

3. Augier, M., Teece, D. 2009. Dynamic capabilities and the role of managers in business strategy and economic performance. Organization Science, Vol. 20, pp. 410-421. http://dx.doi.org/10.1287/orsc.1090.0424

4. Barrera, V., De los Ríos, I., Coronel, J.; Cruz, E. 2010. Analysis of available capitals in farming systems of rural communities: the case of Saraguro, Ecuador. Spanish Journal Agricultural Research, Vol. 8, Iss. 4, pp. 1191-1207.

5. Berkes, F., Folke, C. 1998. Linking social and ecological systems for resilience and sustainability. Linking social and ecological systems: management practices and social mechanisms for building resilience, Vol. 1, pp. 13-20.

6. Camposeven. 2014. Documentos internos de la organización. Sociedad Agraria de Transformación Camposeven. Murcia. (In Spain)

7. Cazorla, A., De los Ríos, I. 2012. Rural Development as "Working With People": a proposal for policy management in public domain. Madrid: Cazorla, A. \& De los Ríos, I. Retrieved on March, 29, 2012.

8. Cazorla, A., De los Rios, I., Salvo, M. 2013. Working With People (WWP) in Rural Development Proyects: a Proposal from Social Learning. Cuadernos de Desarrollo Rural, pp. 131-157.

9. Darnhofer, I., De los Rios, I., Knickel, K., Koopmans, M., Lamine, C., Almored, G., Tisenkopfs, T. 2014. Rethinking the links between farm modernisation, rural development and resilience in a world of increasing demands and finite resources. Of European Commission, RURAGRI. Ghent: ERA-NET.

10. Davoudi, S., Brooks, E., Mehmood, A. 2013. Evolutionary resilience and strategies for climate adaptation. Planning Practice and Research, Vol. 28, Iss. 3, pp. 307-322. http://dx.DOI:10.1080/02697459.2013.787695

11. De los Ríos, I., Cazorla, A., Díaz-Puente, J., Yagüe, J. 2010. Project-based learning in engineering higher education: two decades of teaching competences in real environments. Procedia: Social and Behavioral Sciences, Vol. 2, Iss. 2, pp. 1368-1378

12. De los Ríos, I., Guillén-Torres, J., Herrera-Reyes, A. T. 2013. Complexity in the management of rural development projects: Case of LASESA (Spain). Cuadernos de Desarrollo Rural, Vol. 10, Iss. 71, pp. 167-186. (In Spain)

13. De los Ríos-Carmenado, I., Rahoveanu, A. T., Gallegos, A. A. 2014. Project management competencies for regional development in Romania: analysis from "Working with People" model. Procedia Economics and Finance, Vol. 8, pp. 614-621.

14. Diaz-Puente, J. M., Cazorla, A., De los Rios, I. 2009. Policy support for the diffusion of innovation among SMEs: An evaluation study in the Spanish region of Madrid. European PlanningStudies, Vol. 17, Iss. 3, pp. 365-387.

15. Folke, C., Colding, J., Berkes, F. 2003. Synthesis: building resilience and adaptive capacity in social-ecological systems. In: F. Berkes, J. Colding and C. Folke (Eds.). Navigating socialecological systems. Building resilience for complexity and change. Cambridge: Cambridge University Press, pp. 352-387.

16. Folke, C., Carpenter, S., Walker, B., Scheffer, M., Chapin, T., Rockström, J. 2010. Resilience thinking: integrating resilience, adaptability and transformability. Ecology and Society, Vol. 15, No. 4, Art. 20. http://www.ecologyandsociety.org/vol15/iss4/art20/

17. Gallopín, G. C. 2006. Linkages between vulnerability, resilience and adaptive capacity. Global Environmental Change, Vol. 16, pp. 293-303.

18. Holling, C. S. 1973. Resilience and stability of ecological systems. Annual Review of Ecology and Systematics, Vol. 4, pp. 1-23.

19. INFO. 2013. Área Cartagena. Living, working, enyoing...Instituto de Fomento de la Región de Murcia.

20. INFO. 2014. Informe sectorial. El sector hortofrutícola en la Región de Murcia. Mayo 2014. Instituto de Fomento Región de Murcia. (In Spain)

21. Lloyd, M. G., Peel, D., Duck, R. W. 2013. Towards a social-ecological resilience framework for coastal planning. Land Use Policy, Vol. 30, pp. 925-933.

22. MAGRAMA. 2014. Dossier Autonómico Región de Murcia, Enero 2014. Análisis y Prospectiva - serie Territorial, Subdirección General de Análisis, Prospectiva y Coordinación. Edita: Ministerio de Agricultura, Alimentación y Medio Ambiente Secretaría General Técnica. (In Spain)

23. Olsson, P., Folke, C., Berkes, F. 2004. Adaptive comanagement for building resilience in social-ecological systems. Environmental Management, Vol. 34, Iss. 1, pp. 75-90.

24. Rethink (nd). Consulted 2nd February 2015. http://www.rethink-net.eu/home.html 
25. Rose, A., Liao, S.-Y. 2005. Modeling Region al Economic Resilience to Disasters: A Computable General Equilibriu1n Analysis of Water Service Disruptions, Journal of Regional Science, Vol. 45, Iss. 1, pp. 75-112.

26. Shucksmith, M., Rønningen, K. 2011. The Uplands after neoliberalism? The role of the small farm in rural sustainability. Journal of Rural Studies, Vol. 27, pp. 275-287. http://dx.doi.org/10.1016/j.jrurstud.2011.03.003

27. Teece, D. 2007. Explicating dynamic capabilities: the nature and microfoundations of (sustainable) enterprise performance. Strategic Management Journal, Vol. 28, pp. 1319-1350.

28. Walker, B., Holling, C. S., Carpenter, S., Kinzig, A. 2004. Resilience, adaptability and transformability in social-ecological systems. Ecology and Society, Vol. 9, Iss. 2, 5 p. http://www.ecologyandsociety.org/vol9/iss2/art5

29. Wallace, W. A., von Wi nterfeldt, D. 2003. A framework to quantitatively assess and enhance the seismic resilience of communities. Earthquake Spectra, Vol. 19, Iss. 4, pp. 733-752.

30. Wears, R. L., Perry, S. J. 2008. A Systems Dynamics Representation of Resilience, 3rd Syn1posiunt on Resilience Engineering. Juan-le-Pins, France.

31. Widgren, M. 2012. Resilience thinking versus political ecology: understanding the dynamics of small-scale, labour-intensive farming landscapes. In: T. Plieninger and C. Bieling (Eds.). Resilience and the cultural landscape. Cambridge: Cambridge University Press, pp. 95-110. http://dx.doi.org/10.1017/cbo9781139107778.008 